\title{
Laparoscopic Right Adrenalectomy in a Large Right Adrenal Oncocytic Carcinoma
}

\author{
Gabriel Cárdenas, $\mathrm{MD}^{1}$, Mauro Valentini, $\mathrm{MD}, \mathrm{PhD}^{1}$, Begoña Mellado, $\mathrm{MD}, \mathrm{PhD}^{2}$, Mayra Velásquez, $\mathrm{MD}^{3}$, \\ Rocío Cardozo, $\mathbf{M D}^{4}$, Josep María Argiles, $\mathrm{MD}^{5}$, Luis Tresierra, $\mathbf{M D}^{1}$, Hassan Tahmaz, $\mathrm{MD}^{1}$, \\ Elvis Vargas, $\mathbf{M D}^{1}$, Rafael Díaz del Gobbo ${ }^{1}$, and César Ginestà, $\mathbf{M D}^{1}$ \\ ${ }^{1}$ Department of General and Digestive Surgery, Hospital HM Delfos, Barcelona, Spain; ${ }^{2}$ Department of Oncology, \\ Hospital HM Delfos, Barcelona, Spain; ${ }^{3}$ Department of Endocrinology, Hospital HM Delfos, Barcelona, Spain; \\ ${ }^{4}$ Department of Anatomical Pathology, Hospital HM Puerta del Sur, Madrid, Spain; ${ }^{5}$ Department of Radiology, Hospital \\ HM Delfos, Barcelona, Spain
}

\begin{abstract}
Background. Adrenocortical carcinomas are rare and aggressive tumors. The recently described oncocytic subtype has been reported approximately 40 times in the literature. ${ }^{1}$ In this video, we describe an unusual case of a large adrenal oncocytic carcinoma, its minimally invasive approach, and its anatomopathological features.

Case description. A 43-year-old male presented to the emergency room with acute abdominal pain and fever. Blood tests showed 20,000 white blood cells and a reactive C-protein of 25. Tomography showed a large right adrenal tumor with necrosis. Antibiotics were started at the intensive care unit. A complete study showed normal tests, including hormones, cortisol, and metanephrines. At the multidisciplinary team meeting it was decided to perform a right transabdominal laparoscopic adrenalectomy. The tumor was approached from the medial side to the lateral side, always controlling the inferior vena cava. Indocyanine green was used to identify vascular structures. Anatomical pathology revealed a $15 \mathrm{~cm}$ lesion corresponding to a malignant adrenal oncocytic carcinoma
\end{abstract}

Electronic supplementary material The online version of this article (https://doi.org/10.1245/s10434-020-09387-5) contains supplementary material, which is available to authorized users.

(C) Society of Surgical Oncology 2020

First Received: 11 August 2020

Accepted: 8 November 2020;

Published Online: 26 November 2020

G. Cárdenas, MD

e-mail: gcardenas.md@gmail.com according to the modified Lin-Weis-Bisceglia criteria. ${ }^{2}$ The patient was discharged without complications on the fifth day. $\mathrm{He}$ is receiving mitotane and is disease-free 5 months after surgery.

Conclusions. Oncocytic subtype is a rare entity described only a few times in the literature. Surgical treatment is of choice due to its curative potential, and the open versus laparoscopic approach will be chosen depending on the size of the tumor and the surgeon's experience. It is believed that this subtype may have a less aggressive behavior than the typical adrenal carcinoma, ${ }^{1}$ therefore its better understanding may help to define therapeutic decisions and prognosis in the future.

DISCLOSURES Gabriel Cárdenas, Mauro Valentini, Begoña Mellado, Mayra Velásquez, Rocío Cardozo, Josep María Argiles, Luis Tresierra, Hassan Tahmaz, Elvis Vargas, Rafael Díaz del Gobbo, and César Ginestà declare no affiliation or financial involvement with any organization.

\section{REFERENCES}

1. Mills JK, Khalil M, Pasieka J, Kong S, Xu Y, Harvey A. Oncocytic subtypes of adrenal cortical carcinoma: aggressive in appearance yet more indolent in behavior? Surgery 2019;166(4):524-33. h ttps://doi.org/10.1016/j.surg.2019.05.049.

2. Bisceglia M, Ludovico O, Di Mattia A, et al. Adrenocortical oncocytic tumors: report of 10 cases and review of the literature. Int J Surg Pathol. 2004;12(3):231-43. https://doi.org/10.1177/ 106689690401200304.

Publisher's Note Springer Nature remains neutral with regard to jurisdictional claims in published maps and institutional affiliations. 